\title{
Review
}

Clinical

nephron

Practice

Published online: November 19, 2014

DOI: $10.1159 / 000368591$

\section{Complement and Glomerular Diseases}

\author{
Reena J. Popat Michael G. Robson \\ King's College London, London, UK
}

\section{Key Words \\ Atypical haemolytic uraemic syndrome . \\ C3 glomerulopathy · Complement pathway}

\begin{abstract}
The complement pathway is a central part of the innate immune system and also modulates adaptive immunity. It is implicated in the pathogenesis of glomerular disease by a number of clinical findings. These include the presence of complement components in renal biopsy samples, decreases in circulating levels indicating consumption, the presence of autoantibodies to complement proteins and the association of genetic mutations with disease either in individuals or within families. Further support and mechanistic insights comes from animal models. This review provides an overview of the role of complement in glomerular diseases and discusses the data from patients and animal models with reference to specific diseases. These include atypical haemolytic uraemic syndrome, C3 glomerulopathy, anti-neutrophil cytoplasmic antibody vasculitis, lupus nephritis and membranous nephropathy. The implications for therapy are also discussed.

(c) 2014 S. Karger AG, Basel
\end{abstract}

\section{Introduction}

Complement is a system of proteins with activities that include the recruitment of inflammatory cells, cellular activation, cell lysis, antimicrobial defence, clear- ance of immune complexes and amplification of the humoral immune response. For an overview the reader is referred to a review such as [1]. The clinical evidence that complement plays a role in the pathogenesis of glomerular disease has several strands. The presence of complement components, identified in renal biopsy samples by immunofluorescence or immunohistochemical staining, is consistent with a pathogenic role, but equally may be incidental. Likewise the presence of low serum levels of complement components, suggesting activation and consumption, or of autoantibodies against complement components is suggestive, but not firm evidence, of a contribution to tissue injury. The association of some types of glomerular disease with genetic abnormalities of complement components is stronger evidence, particularly when this is familial. Data from animal models provide important evidence on the mechanisms through which the complement pathway may contribute to glomerular disease. However, it is important to appreciate the limitations of the model being used. In this article we will give an overview of the evidence from clinical data and animal models that complement is important in a number of specific glomerular diseases, and discuss the therapeutic implications.

Biologic Treatment in Glomerular Disease D. Jayne, Cambridge

V. Tesar, Prague

\section{KARGER}

E-Mail karger@karger.com

www.karger.com/nec
(C) 2014 S. Karger AG, Basel

$1660-2110 / 14 / 1284-0238 \$ 39.50 / 0$
Dr. Michael G. Robson

King's College London, Medical Research Council (MRC) Centre for Transplantation Guy's Hospital

London SE1 9RT (UK)

E-Mail Michael.robson@kcl.ac.uk 


\section{Haemolytic Uraemic Syndrome}

Atypical haemolytic uraemic syndrome (aHUS) and C3 glomerulopathy are diseases in which the primary cause is thought to involve uncontrolled activation of the alternative pathway of complement. Like typical or diarrhoea-associated HUS, aHUS is marked by the presence of thrombocytopenia, haemolytic anaemia and thrombotic microangiopathy primarily affecting the kidneys. Mutations in factor $\mathrm{H}$ occur in around $25 \%$ of cases. Mutations in factor I, membrane cofactor protein and C3 have all been associated with aHUS, though less often than factor $\mathrm{H}$. Autoantibodies to factor $\mathrm{H}$ have also been found in around $10 \%$ of patients with aHUS, and rarely antibodies against factor I. These cases are reviewed in detail in [2]. The mutations in factor $\mathrm{H}$ are primarily found at the $\mathrm{C}$ terminus in the region associated with membrane binding. This is consistent with the model in which dysregulation of the alternative pathway occurs at the endothelial cell surface rather than in the fluid phase.

An elegant mouse model of aHUS was created by expressing a mutant factor $\mathrm{H}$ lacking the $\mathrm{C}$ terminal domains, confirming that these mutations are causative [3]. Breeding of this transgenic mouse with $\mathrm{C} 5$-deficient mice has subsequently shown that C5 and the terminal pathway of complement is key to tissue injury [4]. This supports the rationale for the use of eculizumab in aHUS, which is discussed elsewhere in this issue. The majority of cases of HUS (typical HUS) are associated with Shiga toxin-producing Escherichia coli infection. Even in these cases where endothelial damage is initially caused by the toxin, there is evidence that the alternative pathway is activated and makes a contribution. In an animal model of Shiga toxin-induced HUS, factor B-deficient mice were protected [5].

\section{C3 Glomerulopathy}

There has recently been an increased awareness that many cases of mesangiocapillary glomerulonephritis (MCGN), also referred to as membranoproliferative glomerulonephritis, may be immunoglobulin negative, or have a predominance of $\mathrm{C} 3$ immunostaining. These are now referred to as $\mathrm{C} 3$ glomerulonephritis. This has led to the concept of the immunoglobulin-negative $\mathrm{C} 3$ glomerulopathies which may also include type II MCGN (dense deposit disease) and complement factor $\mathrm{H}$-related protein 5 (CFHR5) nephropathy [6]. These are distinct from the immunoglobulin-positive MCGN usually associated hepatitis B or C, endocarditis, autoimmune disease, or a monoclonal gammopathy. The genetic basis for C3 glomerulopathies is demonstrated most convincingly in familial reports and also supported by association studies in individual patients. Here we will outline the main findings from this body of work and the reader is referred to recent reviews for further detail and references [7]. There are reports of families in which affected members with $\mathrm{C} 3$ glomerulonephritis or dense deposit disease have a mutation leading to uncontrolled alternative pathway activation. These mutations may be in factor $\mathrm{H}$ or $\mathrm{C} 3$ (leading to a factor $\mathrm{H}$-resistant $\mathrm{C} 3$ convertase). Although these comprise a small number of cases, they are important because they provide strong evidence that abnormal complement activation is causative. CFHR 5 nephropathy is a particular form of C3 glomerulopathy that has recently been described in Cypriot families [8]. An abnormally large CFHR5 inhibits the action of factor $\mathrm{H}$, and its histology may have a mesangioproliferative or MCGN pattern. In addition to these reports of familial disease, there are reports of individual patients with mutations in factor $\mathrm{H}$, factor I or CD46, and a suggestion that common variations in factor H, CFHR5, C3 or CD46 may confer an increased risk of $\mathrm{C} 3$ glomerulopathy. C3 nephritic factor is an autoantibody that binds to a neoepitope and stabilises the C3 convertase. It is found in the majority of patients with dense deposit disease, and around half of those with C3 glomerulopathy [9]. Autoantibodies against other components such as factor $\mathrm{H}$, factor $\mathrm{B}$ and $\mathrm{C} 3 \mathrm{~b}$ have also been less frequently reported. However, since patients with C3 glomerulopathy may have mutations in complement genes in addition to autoantibodies, and autoantibodies may also occur in patients with MCGN type I or normal subjects, the role of the autoantibodies in pathogenesis is not clear.

Results from animal models have supported the concept that uncontrolled fluid-phase alternative pathway activation may lead to a C3 glomerulopathy. The original evidence for this came from the observation of MCGN (C3 glomerulopathy) in pigs with a naturally occurring deficiency of factor $\mathrm{H}$ [10]. This was later confirmed by the generation of factor H-deficient mice [11]. One should note that these mice are deficient in factor $\mathrm{H}$, in contrast to the mice referred to above expressing mutant factor $\mathrm{H}$ that develop aHUS. The latter mice can regulate fluid-phase complement activation and have a defect in regulation at the endothelial surface only. By breeding factor H-deficient mice with mice deficient in factor $\mathrm{B}$, the need for uncontrolled activation of the alternative pathway was demonstrated. Furthermore, the presence of factor I is neces- 
sary in disease induction as mice deficient in both factor $\mathrm{H}$ and factor I did not develop disease [12]. Factor I cleaves $\mathrm{C} 3 \mathrm{~b}$ into $\mathrm{iC} 3 \mathrm{~b}$ and $\mathrm{C} 3 \mathrm{dg}$, and the deposition of these cleaved C3 fragments is necessary for disease development. C5 was also shown to play a role in this model [13].

\section{Anti-Neutrophil Cytoplasmic Antibody Vasculitis}

The concept that anti-neutrophil cytoplasmic antibody (ANCA) vasculitis was pauci-immune was challenged by the observation that electron dense deposits occur in 54\% of cases [14]. Following this, data from China has shown that complement components $\mathrm{C} 3, \mathrm{C} 4 \mathrm{C} 1 \mathrm{q}$, factor $\mathrm{B}$, properdin, mannose-binding lectin $(\mathrm{MBL})$ and the terminal pathway membrane attack complex are deposited in the glomeruli of some patients with ANCA vasculitis and focal necrotising glomerulonephritis [14-16]. Mice which were depleted of complement by treatment with cobra venom factor were protected from disease induced by anti-MPO antibodies, suggesting that complement deposition has pathological consequences and mediates tissue injury [17]. In addition, C5-deficient mice and factor B-deficient but not C4-deficient mice were protected. The nature of the factors that are released by activated neutrophils which cause the initial activation of the alternative pathway remains a key question.

Subsequent work confirmed that the terminal complement pathway was important as treatment with an antiC5 monoclonal antibody protected mice from disease [18]. C5a generated from serum by neutrophils activated by ANCA was shown to mediate further neutrophil priming for a respiratory burst in response to ANCA [19]. Furthermore, the importance of this priming effect was shown in vivo as C5a-receptor-deficient mice were protected from disease. This work has recently been extended with evidence of therapeutic efficacy for the C5a receptor antagonist CCX168 in mice in which the C5a receptor has been replaced with the human equivalent [20]. In addition, disease was exacerbated in mice defective in the second $\mathrm{C} 5 \mathrm{a}$ receptor $\mathrm{C} 5 \mathrm{~L} 2$. The role of C5L2 is not clear in some contexts, but in others and in ANCA vasculitis, it appears to have an anti-inflammatory role.

\section{Systemic Lupus Erythematosus}

A 'full house' of complement and immunoglobulin components is a characteristic finding in lupus nephritis renal biopsies. A low serum C3 or C4 correlates with dis- ease activity in some patients, and anti-C1q antibodies are associated with lupus nephritis. A genetic deficiency of classical pathway complement components predisposes to SLE as reviewed in [21]. A number of mechanisms may be responsible including the defective clearance of both apoptotic cells and immune complexes. Alternatively or in addition, complement deficiency may promote a loss of tolerance to autoantigens. Although a genetic deficiency occurs in a small number of patients, an acquired hypocomplementaemia, due to active lupus, may serve to exacerbate disease by similar mechanisms.

The clinical observations described above suggest that complement is important in lupus nephritis. Mice with triple deficiency of $\mathrm{C} 1 \mathrm{q}, \mathrm{C} 2$ and factor $\mathrm{B}$, develop spontaneous autoantibody production and glomerulonephritis [22], showing that complement activation is not required for lupus-like glomerulonephritis. Data in the C3-deficient MRLlpr lupus-prone mice also support this suggestion [23]. In contrast, other findings suggest complement can play a proinflammatory role in lupus. MRLlpr mice deficient in the complement regulator DAF have accelerated disease [24] and antibodies to C5 ameliorate disease [25]. Although the $\mathrm{C} 3 \mathrm{a}$ receptor appears to promote a degree of protection (by mechanisms that are not clear) [26], the C5a receptor can stimulate disease through $\mathrm{T}$ cell-mediated effects [27]. Anti-C1q antibodies were shown to exacerbate immune complex-mediated glomerulonephritis in mice, suggesting that in patients anti-C1q antibodies may contribute to pathogenesis [28]. Overall the data from animal models are conflicting and the role of complement in causing tissue injury is not clear.

\section{Membranous Nephropathy}

In idiopathic membranous nephropathy, subepithelial deposits cause thickening of the glomerular basement membrane without an inflammatory component. Immunostaining shows predominantly IgG and C3 deposition. IgG is predominantly IgG4, which is a poor activator of the classical pathway, and there is usually an absence of classical pathway complement components on immunostaining. The terminal pathway membrane attack complex has also been found, though this is not tested routinely in clinical practice. These observations suggest that the alternative and terminal pathways may play a role. Heyman nephritis is a rat model in which an immune response against a podocyte protein called megalin is induced. The histological changes are similar to membranous nephropathy and so this is a plausible model of 
the human disease. Data derived from this model has shown that C6-deficient rats are protected, suggesting a role for terminal complement components in pathogenesis [29].

\section{Implications for Therapy}

In the preceding sections we have given an overview of the current understanding of the role of complement in aHUS, C3 glomerulopathy, ANCA vasculitis, SLE and membranous nephropathy.

In patients with aHUS, replacement with normal complement components by plasma exchange has been effective in some cases. Eculizumab, a humanised monoclonal antibody against $\mathrm{C} 5$, is effective in aHUS and has recently gained FDA approval [30]. There are also reports of its use in patients with typical HUS and in C3 glomerulopathy. A detailed discussion of eculizumab for these conditions is presented in other chapters of this issue. There is also a strong rationale for the use of eculizumab in membranous nephropathy, and a randomised controlled trial of $200 \mathrm{pa}-$ tients was performed and presented in 2002 that did not show a benefit [31]. In this study, however, complement inhibition was incomplete and therefore the role of terminal complement pathway inhibition as a therapeutic op- tion in membranous nephropathy remains unresolved. Rituximab is now an alternative to cyclophosphamide in patients with ANCA vasculitis. However, there remains a need for new anti-inflammatory therapies to replace or reduce the need for corticosteroids which lead to significant adverse effects. Anti-C5 therapy and C5a inhibition have both shown benefit in animal models of anti-MPO vasculitis as mentioned above. As a result of this, phase II trials in ANCA vasculitis are underway with both eculizumab and CCX168, an orally available small molecule $\mathrm{C} 5 \mathrm{aR}$ antagonist. As we have illustrated, the role of complement in lupus is complex and the outcomes of complement inhibition in patients would be difficult to predict. Consequently, there are no clinical trials of eculizumab or other complement inhibitors in lupus.

\section{Acknowledgments}

The authors have received recent research funding from Kidney Research UK and the Medical Research Council. They have also received funding and support from the National Insitute for Health Research (NIHR) Biomedical Research Centre based at Guy's and St Thomas' NHS Foundation Trust and King's College London. The views expressed are those of the author(s) and not necessarily those of the NHS, the NIHR or the Department of Health. They are also supported by the MRC Centre for Transplantation.

\section{References}

1 Ricklin D, Hajishengallis G, Yang K, Lambris JD: Complement: a key system for immune surveillance and homeostasis. Nat Immunol 2010;11:785-797.

2 Kavanagh D, Goodship TH, Richards A: Atypical hemolytic uremic syndrome. Semin Nephrol 2013;33:508-530.

-3 Pickering MC, de Jorge EG, Martinez-Barricarte R, Recalde S, Garcia-Layana A, Rose KL, Moss J, Walport MJ, Cook HT, de Cordoba SR, Botto M: Spontaneous hemolytic uremic syndrome triggered by complement factor $\mathrm{H}$ lacking surface recognition domains. J Exp Med 2007;204:1249-1256.

4 de Jorge EG, Macor P, Paixao-Cavalcante D, Rose KL, Tedesco F, Cook HT, Botto M, Pickering MC: The development of atypical hemolytic uremic syndrome depends on complement C5. J Am Soc Nephrol 2010;22:137-145.

5 Morigi M, Galbusera M, Gastoldi S, Locatelli M, Buelli S, Pezzotta A, Pagani C, Noris M, Gobbi M, Stravalaci M, Rottoli D, Tedesco F, Remuzzi G, Zoja C: Alternative pathway activation of complement by Shiga toxin promotes exuberant $\mathrm{C} 3 \mathrm{a}$ formation that triggers microvascular thrombosis. J Immunol 2011; 187:172-180.
-6 Sethi S, Fervenza FC: Membranoproliferative glomerulonephritis - a new look at an old entity. N Engl J Med 2012;366:11191131.

-7 Barbour TD, Pickering MC, Cook HT: Recent insights into C3 glomerulopathy. Nephrol Dial Transplant 2013;28:1685-1693.

-8 Gale DP, de Jorge EG, Cook HT, MartinezBarricarte R, Hadjisavvas A, McLean AG, Pusey CD, Pierides A, Kyriacou K, Athanasiou Y, Voskarides K, Deltas C, Palmer A, Fremeaux-Bacchi V, de Cordoba SR, Maxwell PH, Pickering MC: Identification of a mutation in complement factor H-related protein 5 in patients of Cypriot origin with glomerulonephritis. Lancet 2010;376:794801.

-9 Servais A, Noel LH, Roumenina LT, Le Quintrec M, Ngo S, Dragon-Durey MA, Macher MA, Zuber J, Karras A, Provot F, Moulin B, Grunfeld JP, Niaudet P, Lesavre P, FremeauxBacchi V: Acquired and genetic complement abnormalities play a critical role in dense deposit disease and other $\mathrm{C} 3$ glomerulopathies. Kidney Int 2012;82:454-464.

10 Jansen JH, Hogasen K, Mollnes TE: Extensive complement activation in hereditary porcine membranoproliferative glomerulonephritis type II (porcine dense deposit disease). Am J Pathol 1988;143:1356-1365.

-11 Pickering MC, Cook HT, Warren J, Bygrave AE, Moss J, Walport MJ, Botto M: Uncontrolled C3 activation causes membranoproliferative glomerulonephritis in mice deficient in complement factor H. Nat Genet 2002;31: 424-428.

12 Rose KL, Paixao-Cavalcante D, Fish J, Manderson AP, Malik TH, Bygrave AE, Lin T, Sacks SH, Walport MJ, Cook HT, Botto M, Pickering MC: Factor I is required for the development of membranoproliferative glomerulonephritis in factor $\mathrm{H}$-deficient mice. J Clin Invest 2008;118:608-618.

13 Pickering MC, Warren J, Rose KL, Carlucci F, Wang Y, Walport MJ, Cook HT, Botto M: Prevention of $\mathrm{C} 5$ activation ameliorates spontaneous and experimental glomerulonephritis in factor H-deficient mice. Proc Natl Acad Sci U S A 2006;103:9649-9654.

14 Chen M, Xing GQ, Yu F, Liu G, Zhao MH: Complement deposition in renal histopathology of patients with ANCA-associated pauciimmune glomerulonephritis. Nephrol Dial Transplant 2009;24:1247-1252. 
15 Xing GQ, Chen M, Liu G, Heeringa P, Zhang JJ, Zheng X, E J, Kallenberg CG, Zhao MH: Complement activation is involved in renal damage in human antineutrophil cytoplasmic autoantibody associated pauci-immune vasculitis. J Clin Immunol 2009;29:282-291.

-16 Xing GQ, Chen M, Liu G, Zheng X, E J, Zhao $\mathrm{MH}$ : Differential deposition of C4d and MBL in glomeruli of patients with ANCA-negative pauci-immune crescentic glomerulonephritis. J Clin Immunol 2010;30:144-156.

-17 Xiao H, Schreiber A, Heeringa P, Falk RJ, Jennette JC: Alternative complement pathway in the pathogenesis of disease mediated by antineutrophil cytoplasmic autoantibodies. Am J Pathol 2007;170:52-64.

-18 Huugen D, van Esch A, Xiao H, Peutz-Kootstra CJ, Buurman WA, Tervaert JW, Jennette JC, Heeringa P: Inhibition of complement factor C5 protects against anti-myeloperoxidase antibody-mediated glomerulonephritis in mice. Kidney Int 2007;71:646-654.

19 Schreiber A, Xiao H, Jennette JC, Schneider W, Luft FC, Kettritz R: C5a receptor mediates neutrophil activation and ANCA-induced glomerulonephritis. J Am Soc Nephrol 2009; 20:289-298.

-20 Xiao H, Dairaghi DJ, Powers JP, Ertl LS, Baumgart T, Wang Y, Seitz LC, Penfold ME, Gan L, Hu P, Lu B, Gerard NP, Gerard C, Schall TJ, Jaen JC, Falk RJ, Jennette JC: C5a receptor (CD88) blockade protects against MPO-ANCA GN. J Am Soc Nephrol 2013;25: 225-231.
21 Pickering MC, Botto M, Taylor PR, Lachmann PJ, Walport MJ: Systemic lupus erythematosus, complement deficiency and apoptosis. Adv Immunol 2000;76:227-324.

22 Mitchell DA, Taylor PR, Cook HT, Moss J, Bygrave AE, Walport MJ, Botto M: Cutting edge: $\mathrm{Clq}$ protects against the development of glomerulonephritis independently of C3 activation. J Immunol 1999;162:5676-5679.

23 Sekine H, Reilly CM, Molano ID, Garnier G, Circolo A, Ruiz P, Holers VM, Boackle SA, Gilkeson GS: Complement component C3 is not required for full expression of immune complex glomerulonephritis in MRL/lpr mice. J Immunol 2001;166:6444-6451.

24 Miwa T, Maldonado MA, Zhou L, Sun X, Luo HY, Cai D, Werth VP, Madaio MP, Eisenberg RA, Song WC: Deletion of decay-accelerating factor (CD55) exacerbates autoimmune disease development in MRL/lpr mice. Am J Pathol 2002;161:1077-1086.

25 Wang Y, Hu Q, Madri JA, Rollins SA, Chodera A, Matis LA: Amelioration of lupuslike autoimmune disease in NZB/WF1 mice after treatment with a blocking monoclonal antibody specific for complement component C5. Proc Natl Acad Sci U S A 1996;93: 8563-8568.
26 Wenderfer SE, Wang H, Ke B, Wetsel RA, Braun MC: C3a receptor deficiency accelerates the onset of renal injury in the MRL/lpr mouse. Mol Immunol 2009;46:1397-1404.

27 Wenderfer SE, Ke B, Hollmann TJ, Wetsel RA, Lan HY, Braun MC: C5a receptor deficiency attenuates $\mathrm{T}$ cell function and renal disease in MRLlpr mice. J Am Soc Nephrol 2005;16:3572-3582.

28 Trouw LA, Groeneveld TW, Seelen MA, Duijs JM, Bajema IM, Prins FA, Kishore U, Salant DJ, Verbeek JS, van Kooten C, Daha MR: Anti-C1q autoantibodies deposit in glomeruli but are only pathogenic in combination with glomerular Clq-containing immune complexes. J Clin Invest 2004;114:679-688.

29 Leenaerts PL, Hall BM, Van Damme BJ, Daha MR, Vanrenterghem YF: Active Heymann nephritis in complement component C6 deficient rats. Kidney Int 1995;47:16041614.

30 Nurnberger J, Philipp T, Witzke O, Opazo Saez A, Vester U, Baba HA, Kribben A, Zimmerhackl LB, Janecke AR, Nagel $M$, Kirschfink M: Eculizumab for atypical hemolytic-uremic syndrome. N Engl J Med 2009; 360:542-544

31 Appel GB, Nachman PH, Hogan SL, Rodhakrishan J, Old C, Hebert L, Fervenza FC, Kumor K, Petro BE, Li L, Hardman L: Eculizumab (C5 complement inhibitor) in the treatment of idiopathic membranous nephropathy (abstract). J Am Soc Nephrol 2002: 668A-1857A. 